\title{
Impact of solar radiation on the decomposition of detrital leaves of eelgrass Zostera marina
}

\author{
Anssi Vähätalo ${ }^{1,2, *}$, Morten Søndergaard ${ }^{3}$, Louise Schlüter ${ }^{4}$, Stiig Markager $^{5}$ \\ ${ }^{1}$ Department of Ecological and Environmental Sciences, University of Helsinki, Niemenkatu 73, FIN-15210 Lahti, Finland \\ ${ }^{2}$ Department of Applied Chemistry and Microbiology, PO Box 56, FIN-00014 University of Helsinki, Finland ** \\ ${ }^{3}$ Freshwater Biological Laboratory, University of Copenhagen, Helsingorsgade 51, DK-3400 Hillerød, Denmark \\ ${ }^{4}$ The International Agency for ${ }^{14} \mathrm{C}$ Determination, VKI, Institute for the Water Environment, Agern Allé 11, \\ DK-2970 Hørsholm, Denmark \\ ${ }^{5}$ Department of Marine Ecology and Microbiology, National Environmental Research Institute, Frederiksborgvej 399 , \\ DK-4000 Roskilde, Denmark
}

\begin{abstract}
Although seagrass detritus is exposed to high solar radiation in its natural environment, the impact of solar radiation has not yet been taken into account in degradation of particulate detritus. We exposed sterilised detrital leaves of eelgrass Zostera marina $\mathrm{L}$. to solar radiation. Under solar radiation the chlorophyll in leaves bleached in $<5 \mathrm{~d}$ and other absorbing compounds within 1 mo. During a 1 mo period the organic matter content of leaves $\left(32 \mathrm{~g} \mathrm{~m}^{-2}\right.$ of leaves) decreased, mainly via leaching, 3 to $9 \%$ in darkness and 23 to $36 \%$ under solar radiation. First order kinetics described the loss of organic matter as a function of cumulative global radiation well. The decay coefficient was $0.00038 \mathrm{MJ}^{-1} \mathrm{~m}^{2}$ Solar radiation-induced changes in the structure of leaves increased the bioavailability of detritus to bacteria 2- to 3-fold. Our results show that solar radiation is one of the major factors in the decomposition of seagrasses and has to be taken into account in degradation models of particulate detritus.
\end{abstract}

KEY WORDS: Seagrasses · Detritus · Degradation - Photochemistry · Solar radiation · Chlorophyll Bacteria

\section{INTRODUCTION}

Seagrasses are important primary producers in many coastal areas (Mann 1972). Herbivores consume less than $10 \%$ of the production, and most of the seagrass biomass finds its way directly to detritus (Nienhuis \& Groenendijk 1986). The degradation of seagrass detritus is thus one of the major pathways for organic matter in littoral marine environments (Mann 1988).

A conceptual model for the degradation of aquatic angiosperms, including seagrasses, has 3 phases: (1) a rapid initial leaching of dissolved organic matter, (2) a phase of biological activity and (3) a phase with slow degradation of biologically recalcitrant detritus (Godshalk \& Wetzel 1978). Both biological and physical

-E-mail: anssi.vahatalo@helsinki.fi

- Address for correspondence activity degrade and modify detritus. Biological detritus processing includes shredding, grinding and digestion by animals, as well as microbial decay and remineralisation. Physical detritus processing comprises fragmentation of large particles, production of particles from dissolved molecules, flocculation and sedimentation (Odum 1984, Harrison 1989).

The current knowledge of seagrass degradation is based on a large number of decomposition studies both in situ and in the laboratory. In situ degradation of seagrass leaves has been studied mostly in litterbags (reviewed by Harrison 1989), sometimes in a flowing seawater tank (Rublee \& Roman 1982), in a transparent Plexiglas box (Wasserman \& Dumon 1995) or in glass jars at $10 \mathrm{~m}$ depth (Wahbeh \& Mahasneh 1985). In these studies most of the incubated leaves were sheltered from direct solar radiation either by the litterbag material, by a $10 \mathrm{~m}$ column 
of water or by the uppermost leaves of the pile. In laboratory studies seagrasses have typically been incubated in darkness (e.g. Harrison \& Mann 1975, Goldshalk \& Wetzel 1978, Pellikaan 1984, Kristensen 1994). In one case, when the effect of amphipods on degradation was studied, the detritus was exposed to low doses of light (Harrison 1982). Thus, our current knowledge of seagrass degradation is based mainly on experiments which did not take into account the role of solar radiation as a mediating factor.

A few pieces of evidence suggest that solar radiation contributes to the degradation of seagrasses. Dark brown detritus of eelgrass Zostera marina which had spent $700 \mathrm{yr}$ in anaerobic conditions bleached rapidly upon exposure to solar radiation (Boon \& Haverkamp 1982). Similarly, solar radiation resulted in loss of phenols from the leaves of Halodule wrightii (Opsahl \& Benner 1993). Seagrass detritus is exposed to solar radiation in its natural environment, especially when it is floating. Therefore, it is likely that solar radiation affects the decomposition of seagrass detritus.

In the present study we focus on the abiotic photochemical decomposition of detrital leaves of eelgrass. We exposed dark brown detrital leaves of eelgrass Zostera marina to solar radiation. During the course of solar exposure we followed the loss of organic matter and changes in the bioavailability of the detritus.

\section{MATERIAL AND METHODS}

Material and experimental setup. Stranded detrital leaves of eelgrass Zostera marina L. were collected in Roskilde Fjord, Denmark $\left(55^{\circ} 55^{\prime} \mathrm{N}, 12^{\circ} 00^{\prime} \mathrm{E}\right)$ on 24 April (spring) and 28 June (summer) 1997. At the same time water samples were taken from $0.4 \mathrm{~m}$ depth with a bucket. The spring leaves were wet and newly $(<2 \mathrm{~d}$ old) storm-driven to the shore. The summer leaves were partly dry and had been on the shore about 1 wk before sampling

In the laboratory dark brown but otherwise intact leaves were selected, and epiphytes (colonial polyps and Bryozoa) were removed by scratching every leaf from both sides using fingernails. A visually homogenous 4 to $8 \mathrm{~cm}$ long section of each leaf was cut with a paper cutter into pieces. Small (2.5 mm long) pieces of leaves were used for measurements of bacterial activity, $5 \mathrm{~mm}$ long pieces for ash-free dry weight measurements (AFDW), $7.5 \mathrm{~mm}$ long pieces for pigment analysis (in summer only) and $12.5 \mathrm{~mm}$ long pieces for leaf absorption measurements (in spring only). During handling the leaves were kept in littoral water, which turned brownish, indicating some leaching. The width (with $0.1 \mathrm{~mm}$ accuracy) of each leaf was measured for calculation of the area. To maximise the initial homo- geneity of samples, the adjacent pieces of each leaf were separated into different treatments (dark or light) To cover some variability among leaves, 4 leaves were cut for each sample. The preparation of leaves resulted in almost identical dark-light sample pairs. However, different samples showed some variability; for example, the organic matter content of samples ranged from 23.4 to $42.8 \mathrm{~g} \mathrm{AFDW} \mathrm{m}^{-2}$ of leaves (mean $35.3 \pm 1.2, \pm \mathrm{SD}$ ). Three replicates were prepared in spring and 6 in summer

In order to study the effects of solar radiation on the decomposition without any biological interference, the pieces of leaves were dry-heat sterilised at $105^{\circ} \mathrm{C}$ for 20 to $24 \mathrm{~h}$ and aseptically transferred to sterile polystyrene petri dishes. The petri dishes received 30 or $35 \mathrm{ml}$ of sterile filtered $(0.2 \mu \mathrm{m})$ and autoclaved $(20 \mathrm{~min}$ at $125^{\circ} \mathrm{C}$ ) littoral water. Petri dishes without leaves served as control. The lid of each petri dish was sealed with tape to prevent evaporation of water and contamination of the sample. The concentration of detritus was 93 to $168 \mathrm{mg}$ of organic matter $\mathrm{I}^{-1}$ in spring and 216 to $293 \mathrm{mg}$ organic matter $\mathrm{I}^{-1}$ in summer. The final volume of water in the petri dishes left 40 or $45 \mathrm{ml}$ air space. The petri dishes contained oxygen 6 to 18 times in excess of that needed to decompose all detrital organic matter.

The incubation of the petri dishes took place outdoors and the dishes were exposed to direct sunlight throughout the day. Half of the petri dishes were covered with aluminium foil and the rest were uncovered. The PAR (photosynthetically active radiation) part of the solar radiation penetrated quite well through the lid of the petri dish but part of the UV radiation was retained (Fig. 1). During the incubation (36 d from April to June, and $30 \mathrm{~d}$ in July) water condensed on the inner surface of the lids. This resulted in a $30 \%$ reduction of photosynthetic photon flux density (Li-Cor, LI190SA quantum sensor, $400-700 \mathrm{~nm}$ ). The cumulative global radiation inside the petri dishes was calculated from the global solar radiation measurements made $25 \mathrm{~km}$ from the study site (Department of Agricultural

Fig. 1. Transmittance of radiation through the lid of a polysty rene petri dish

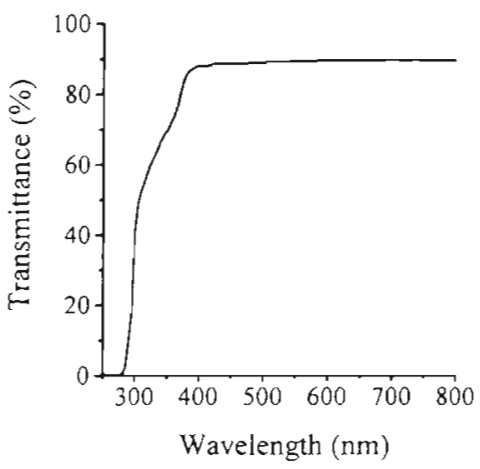


Sciences, The Royal Veterinary and Agricultural University) and corrected for the $30 \%$ reduction. The temperature inside the petri dish was measured with a minimum-maximum thermometer. In the solar radiation-exposed petri dishes temperatures ranged from 0 to $49^{\circ} \mathrm{C}$ in spring and from 9 to $63^{\circ} \mathrm{C}$ in summer. In summer the temperatures inside the dark petri dishes ranged from 13 to $37^{\circ} \mathrm{C}$.

AFDW of leaves and carbon measurements. For dry weight determination, the $5 \mathrm{~mm}$ pieces of leaves were dried at $105^{\circ} \mathrm{C}$ for 13 to $29 \mathrm{~h}$ and weighed with a Chan 29 Automatic Electrobalance. The AFDW (the organic matter content) was determined after ashing at $550^{\circ} \mathrm{C}$ for $3 \mathrm{~h}$. Before the experiments one $5 \mathrm{~mm}$ piece of each leaf was cut for the measurement of initial AFDW. The measured AFDW values were divided by the area cone side) and the results are presented as $\mathrm{g}$ AFDW $\mathrm{m}^{-2}$ of leaves.

The difference in AFDW of the leaves exposed to sunlight and those kept in darkness is the solar radiation-induced loss of organic matter. This loss depended only on the amount of incoming solar radiation and was assumed to follow first order decay kinetics according to:

$$
\frac{\mathrm{dAFDW}}{\mathrm{d} I}=-k \mathrm{AFDW}
$$

where $J=$ cumulative global radiation $\left(\mathrm{MJ} \mathrm{m}^{-2}\right)$ and $k=$ an apparent first order rate constant $\left(\mathrm{MJ}^{-1} \mathrm{~m}^{2}\right)$ for solar radiation-induced loss of AFDW ( $\mathrm{g}$ AFDW $\mathrm{m}^{-2}$ of leaves)

The fine particulate organic carbon (FPOC) content in the water was used to measure fragmentation of leaves. After removing the macroscopic $(2.5$ to $7.5 \mathrm{~mm})$ pieces of leaves from the petri dishes, the remaining particles in the water were collected on pre-ignited $\left(550^{\circ} \mathrm{C}, 3 \mathrm{~h}\right) \mathrm{GF} / \mathrm{F}$ filters (nominal pore size $0.7 \mu \mathrm{m}$, diameter $12 \mathrm{~mm}$ ). The carbon collected on the filters was determined by combusting at $600^{\circ} \mathrm{C}$ and analysing the produced $\mathrm{CO}_{2}$ with an infrared gas analyser (Sondergaard \& Middelboe 1993). The samples harvested at the beginning of the experiments were considered as blanks. The measured FPOC content was divided by the area of leaves in the petri dish and results are given as $\mathrm{g} F P O C \mathrm{~m}^{-2}$ of leaves. The GF/F filtrate was used for the measurement of dissolved organic carbon (DOC). The filtrates were acidified $[0.8 \%$ (v/v) $2 \mathrm{~N}$ $\mathrm{HCl}$ ) and frozen $\left(-20^{\circ} \mathrm{C}\right)$ for later DOC measurements by high temperature, Pt-catalysed oxidation (Shimadzu TOC-5000). After subtraction of DOC in the controls without leaves, the leaching of $\mathrm{DOC}$ is given per $\mathrm{m}^{2}$ of leaves.

Bioavailability of the organic matter of leaves. The bioavailability of the leaves during the course of the summer experiment was measured by a bacterial bioassay. The sterile $2.5 \mathrm{~mm}$ long pieces of leaves from petri dishes were aseptically transferred into $5 \mathrm{ml}$ of sterile filtered and autoclaved littoral water. This suspension received a bacterial inoculum $10 \%$ $\mathrm{v} / \mathrm{v}$ ). An identical inoculum was used for every sample because the bioavailability method is sensitive to the structure and biomass of the initial inoculum. The inoculum was prepared in sterile filtered and autoclaved littoral water, which was amended $(10 \% \mathrm{v} / \mathrm{v})$ with a GF/F-filtrate of the same water (to avoid flagellates). After $4 \mathrm{~d}$ growth at $20^{\circ} \mathrm{C}$ in dim light without shaking, aliquots of the inoculum were frozen $\left(-20^{\circ} \mathrm{C}\right)$. After introduction of the thawed aliquots of inoculum, the bioassay cultures were grown under constant conditions $\left(18\right.$ to $20^{\circ} \mathrm{C}$ in dim light under mild shaking). After $6 \mathrm{~d}$ the incorporation of ${ }^{14} \mathrm{C}$ leucine into trichloroacetic acid (TCA) and ethanol insoluble macromolecules (Hollibaugh \& Wong 1992) was used as a measure for bacterial activity. ${ }^{14} \mathrm{C}$ leucine was introduced to a final concentration of $68 \mathrm{nM}$. After $40 \mathrm{~min}$ incubation under shaking at 18 to $20^{\circ} \mathrm{C}$, samples were killed with TCA $15 \%$ final concentration). The leaves were sonicated for $4 \mathrm{~min}$ with a Branson Sonifier 250 with a $50 \%$ duty cycle to obtain a satisfactory counting geometry in liquid scintillation counting.

The incorporation of ${ }^{14} \mathrm{C}$-leucine reflected the activity and biomass of bacteria supported by the organic matter of leaves during the $6 \mathrm{~d}$ culturing. The bacterial activity was supported both by the DOM (dissolved organic matter) of the littoral water and the organic matter of the leaves. The bacterial activity supported by the incubation water was measured separately with a ${ }^{14} \mathrm{C}$-leucine concentration of $17 \mu \mathrm{M}$ and subtracted to obtain the bacterial activity supported by the organic matter of leaves only. The leucine incorporation rate $\left(\mathrm{nmol} \mathrm{h}{ }^{-1}\right.$ ) was normalised to leaf area.

To assess the sterility of samples the bacterial activity was also measured directly in the water of the petri dishes. The measurements confirmed that the sterile conditions of abiotic samples were maintained throughout the incubation time in spring and most samples in summer. However, after 24 and $30 \mathrm{~d}, 4$ or 5 of the 6 replicates showed some incorporation of ${ }^{14} \mathrm{C}$ leucine to macromolecules. Only the sterile samples are included in the results.

Optics of leaves. During the spring experiment the absorbance of leaves was measured with a Shimadzu UV-VIS double beam spectrophotometer UV-160A. The area of the light beam passing through a leaf was restricted with a black filter with a $1.9 \times 7.7 \mathrm{~mm}$ (14.6 $\mathrm{mm}^{2}$ ) sample slit. A $12.5 \mathrm{~mm}$ piece of leaf was placed over the sample slit in a fixed position. A drop of water attached the filter to the inside wall of a quartz cuvette and kept the leaf wet during the measurement. 
The high absorbance of brown leaves was measured by reducing the intensity of light in the reference photodiode. Black filters with slits smaller than the sample filter (areas of $0.924,1.54$ and $5.24 \mathrm{~mm}^{2}$ ) were used. The reference filters decreased the baseline absorbance to $-1.8,-1.5$ and -0.6 , respectively. The absorbance of a leaf $\left(A_{\text {app }}\right)$ was calculated as the difference between the measured absorbance and the baseline of the reference filter. Strictly speaking, $A_{\text {app }}$ is the sum of 3 constituents: the true absorbance of a leaf $(A)$, and the loss of photons due to scattering and reflection:

$$
A_{\text {app }}=A+\text { scattering }+ \text { reflection }
$$

At $800 \mathrm{~nm}$ the $A_{\text {app }}$ of the most bleached leaf was assumed only to result from scattering and reflection. Accordingly, $A_{\text {app }}$ at $800 \mathrm{~nm}$ of the most bleached leaf was subtracted from the $A_{\text {app }}$ of all other leaves to obtain an estimate for the true absorbance $(A)$. Each piecc of leaf was measured 3 times and the median of measurements was used for further calculations. The spectrum measured during the course of incubation was compared to that measured from the same piece of leaf before drying and incubation. A was integrated from 350 to $800 \mathrm{~nm}$ to obtain the cumulative absorbance and results are given in units of $A \times \mathrm{nm}$.

The absorptance, transmittance and reflectance of green, brown and bleached leaves were determined with a portable spectroradiometer (LI-1800) equipped with an external integrating sphere (1800-12S. Li-Cor). For this purpose fresh green leaves were collected from the sublittoral $(<1 \mathrm{~m}$ depth), detrital dark brown leaves from the shoreline and bleached whitish leaves from the supralittoral on 24 July. A spectrum from 350 to $800 \mathrm{~nm}$ was scanned in $1 \mathrm{~nm}$ steps. Absorbance of a leaf $\left(A\right.$, leaf $\left.^{-1}\right)$ was calculated as

$$
A=-\log _{10}\left(\frac{\text { transmittance }}{1-\text { reflectance }}\right)
$$

Analysis of pigments from the leaves. Pigments were analysed from the $7.5 \mathrm{~mm}$ pieces of leaves of the summer experiment and from the fresh material collected in July. Prior to extraction of pigments from the leaves, test experiments revealed that if the leaves were boiled, as recommended by Jeffrey (1997), the extraction efficiency of both chlorophylls and carotenoids increased. A boiling period of $1 \mathrm{~min}$ was found to be appropriate; a shorter time resulted in lower extraction efficiency, while a longer time resulted in loss and degradation of pigments. After boiling, the leaves were immediately placed in $3 \mathrm{ml}$ chilled acetone, sonicated on ice for $10 \mathrm{~min}$, and stored for $24 \mathrm{~h}$ at $4^{\circ} \mathrm{C}$ for pigment extraction. The absorbance spectrum (350 to $750 \mathrm{~nm}$ ) of the extracts was measured with 0.5 $\mathrm{nm}$ intervals with a Shimadzu UV-2401PC spectrophotometer The absorbance of the extract was nor- malised to represent a leaf according to:

$$
A_{\text {leat }}=\frac{A_{\text {measurea }} V_{\text {e }}}{\text { Area } l}
$$

where $A_{\text {leat }}=$ absorbance per leaf, $A_{\text {measured }}=$ measured absorbance of extract, $V_{\mathrm{e}}=$ extraction volume $\left(\mathrm{m}^{3}\right)$, Area $=$ area of leaves $\left(\mathrm{m}^{2}\right)$ and $l=$ optical pathlength of cuvette (m).

For pigment identification and quantification, the extracts were injected into a Shimadzu LC-10A HPLC system according to the method described by Wright et al. (1991). The HPLC system was calibrated with pigment standards from The International Agency for ${ }^{14} \mathrm{C}$ Determination, Hørsholm, Denmark. Pigment signals were measured by on-line diode array. The HPLC measurements revealed that drying at $105^{\circ} \mathrm{C}$ - a prerequisite for sterilisation and accurate measurements of weight loss - reduced chlorophyll a (chl a) of leaves to $29 \%$ and carotenoids to $<5 \%$ of that before drying. Because chl a became the only important pigment, a simple spectroscopic method was used instead of HPLC for chl a analysis after drying. The observed maximum absorbance $\left(A_{662 \mathrm{~nm}}\right)$ of the acetone extract at the red end of the spectrum was converted to the concentration of chl a. The $A_{662}$ of the extract was calibrated according to the HPLC-determined concentration of chl a $\left(r^{2}=0.91, n=15\right)$. The concentration of pigments was normalised to leaf area.

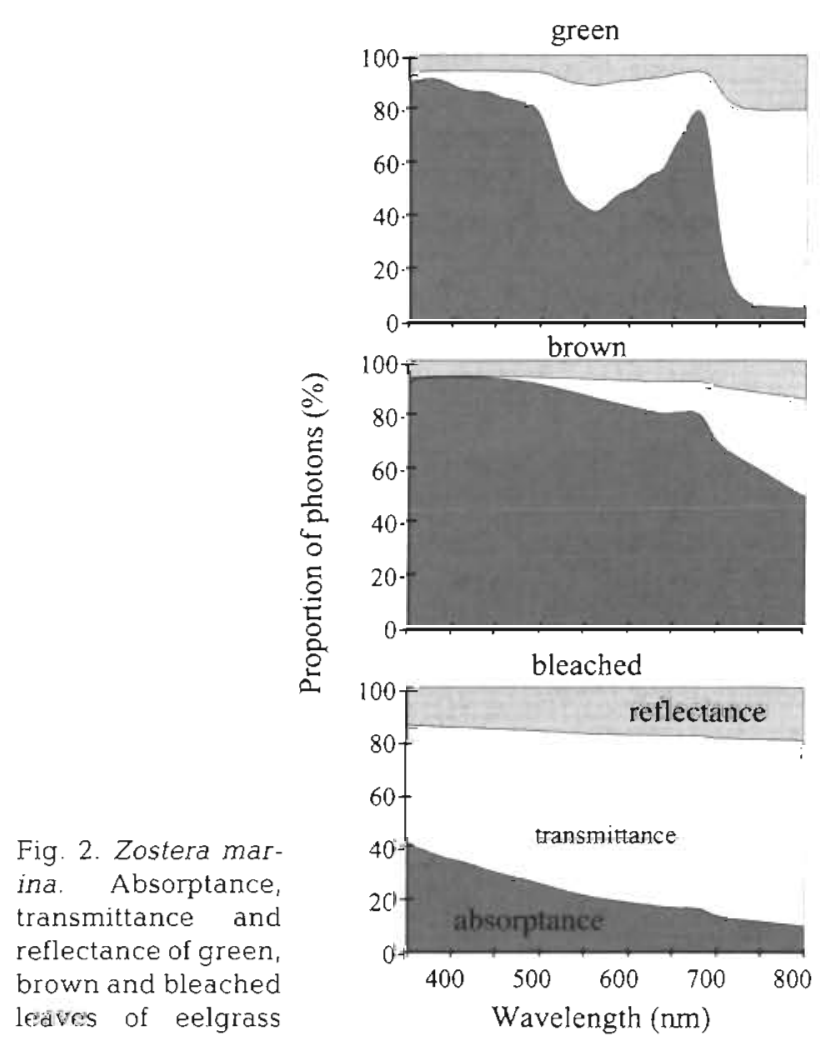




\section{RESULTS}

\section{Decay of absorbing compounds in the leaves of eelgrass}

The absorptance of fresh green leaves resembled the typical absorption spectrum of photosynthetic pigments (Fig. 2). Brown leaves absorbed $>90 \%$ (some leaves up to $99.9 \%$ ) of photons in the near ultraviolet and blue part of the spectrum. Due to the high absorptance, brown leaves were expected to be sensitive to photochemical reactions. The absorptance of bleached leaves was low and most of the photons went through the leaves or were reflected from the surface of the leaves.

To estimate the contribution of pigments to the total absorptance of leaves, the absorptance was converted to absorbance and compared to the absorbance of acetone extract from the same leaves (Fig. 3). The acetone extracts of green leaves showed again the typical spectrum of pigments. The presence of pigments was verified by HPLC (Table 1). In the brown leaves, without any tone of green colour, the concentration of pigments was on average $51 \%$ (ranging from 21 to $79 \%$ for individual pigments) of that in green leaves. Despite the lower concentration of pigments, the total absorbance was higher in brown than in green leaves (Fig. 3), suggesting that some non-pigment components dominated the absorbance of brown leaves. Similarly, the bleached leaves absorbed some radiation although the

Fig. 3. Zostera marina. Total absorbance of leaf and absorbance of acetone extract of the same leaf. The total absorbance was calculated according to Eq. (3)

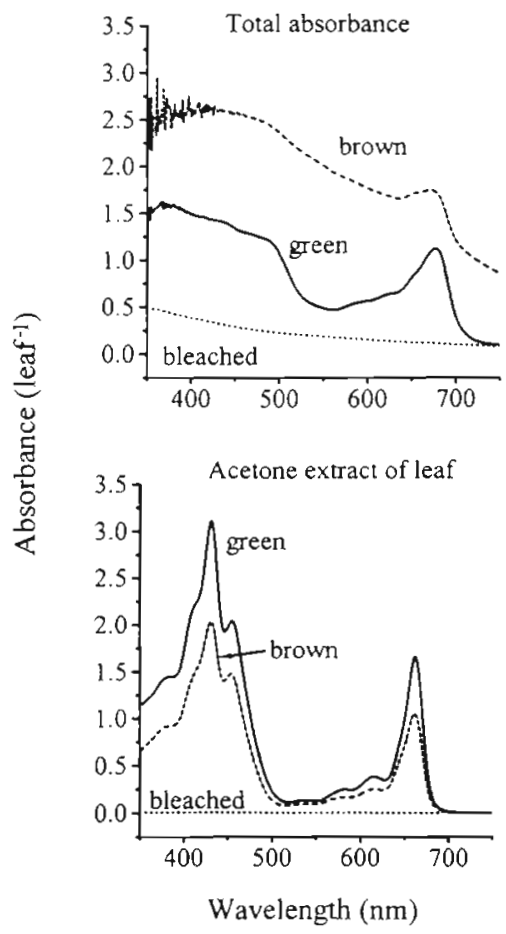

Table 1. Zostera marina. Pigment and organic matter content of green, brown and bleached leaves (mean $\pm \mathrm{SD}$. $\mathrm{n}=5$. bld: below the level of detection

\begin{tabular}{|lccc|}
\hline & Green & $\begin{array}{c}\text { Brown } \\
\text { (mg m }\end{array}{ }^{-2}$ of leaves) & Bleached \\
\hline AFDW & $33639( \pm 6311)$ & $32852( \pm 6479)$ & $25285( \pm 5795)$ \\
Chl $a$ & $295( \pm 105)$ & $136( \pm 85)$ & bld \\
Chl b & $110( \pm 42)$ & $65( \pm 41)$ & bld \\
Lutein & $23( \pm 10)$ & $18( \pm 12)$ & bld \\
B-carotene & $12( \pm 6)$ & $3( \pm 2)$ & bld \\
Neoxanthin & $6( \pm 3)$ & $5( \pm 4)$ & bld \\
Violaxanthin & $5( \pm 3)$ & $2( \pm 2)$ & bld \\
\hline
\end{tabular}

absorption of acetone extract showed no signs of pigments.

Our hypothesis - inspired by Opsahl \& Benner (1993) — is that solar radiation alone degraded the absorbing components of leaves and resulted in bleaching of the leaves (Fig. 2). To verify the hypothesis, sterile brown leaves were exposed to the solar radiation. During the course of solar radiation exposure, the absorbance of leaves at visual wavelengths typically decreased and the peak of absorbance moved gradually towards shorter wavelengths (Fig. 4). After $36 \mathrm{~d}$ the most bleached leaf hardly showed any absorbance.

The bleaching of leaves was quantified by calculating the cumulative absorbance of leaves over the spectrum (Fig. 5). The drying of leaves at $105^{\circ} \mathrm{C}$, before the start of experiment, increased the absorbance $6 \%( \pm 2$, $\mathrm{SD}$ ) (Fig. 5). In darkness the absorbance of brown leaves decreased 7 to $8 \%$ over $36 \mathrm{~d}$. This decrease did not lead to any visual changes in the colour of leaves. The solar radiation-exposed leaves became clearly bleached and during the $36 \mathrm{~d}$ period lost most of their absorbance.

To investigate whether the decomposition of pigments followed the general loss of total absorbance of leaves (Fig. 5), we measured the chl a content of leaves during the summer experiment. During the first $5 \mathrm{~d}$ the leaves lost most $(92 \%)$ of their chl a when exposed to solar radiation (Fig. 6). In darkness abiotic leaching

Fig. 4. Zostera marina, Typical development of the absorbance of sterile brown leaves during exposure to solar radiation. Spectra are shown at the beginning of $(0 \mathrm{~d})$ and after $15 \mathrm{~d}$ exposure, and for 3 leaves after $36 \mathrm{~d}$ exposure

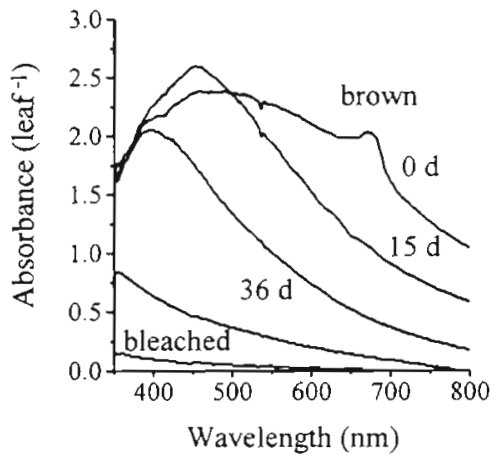


Fig. 5. Zostera marina. Development of the cumulative absorbance of sterile brown leaves kept in darkness (-) or exposed to solar radiation (O). (A) Absolute cumulative absorbance of leaves over the spectrum 350 to $800 \mathrm{~nm}$. (B) Relative changes in the cumulative absorbance. The $x$-axis of A shows the cumulative amount of global radiation which penetrated into the solar radiation-exposed petri dishes. The $x$-axis of $B$ shows the elapsed time

Fig. 6. Zostera marina Development of chlorophyll a content of sterile leaves in darkness (-) and under solar radiation $(0$, mean \pm SD). Number of samples analysed is shown beside the data points
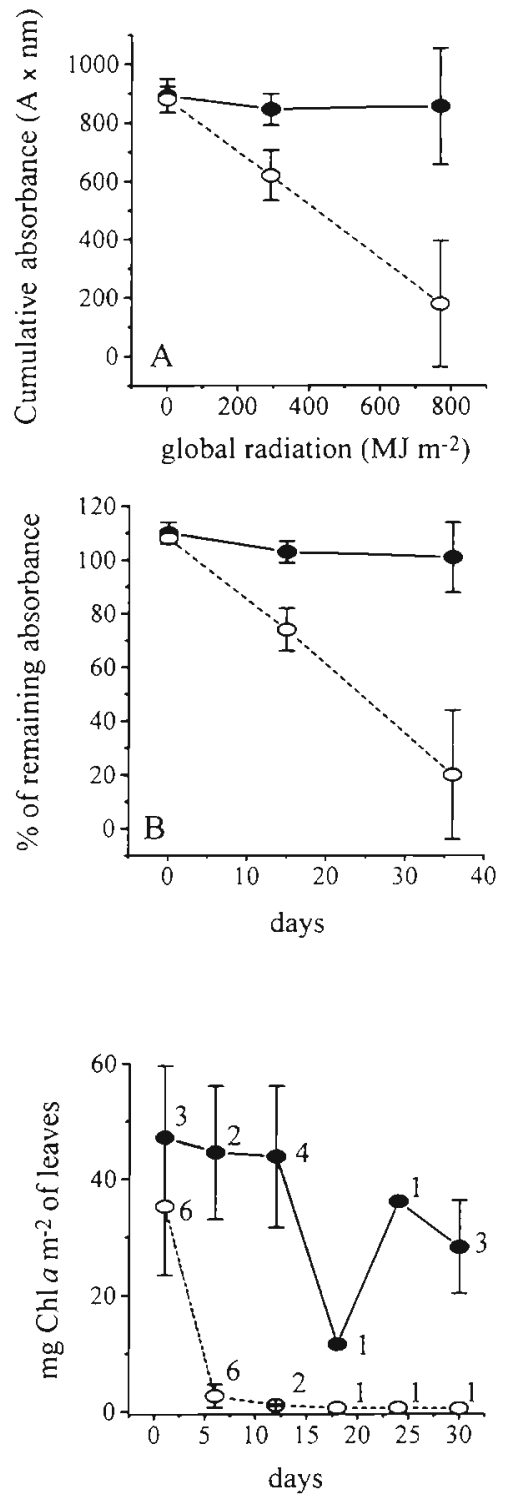

and thermal degradation reduced the concentration of chl a only slightly during the $30 \mathrm{~d}$ long incubation (Fig. 6). Thus, chl a was more sensitive to solar radiation-induced loss than the non-pigment absorbing compounds of leaves (Figs. $5 \& 6$ ).

\section{Loss of AFDW from detrital leaves of eelgrass}

The organic matter content of leaves decreased more under solar radiation than in darkness (Fig. 7 A, B). In spring the difference became evident after $36 \mathrm{~d}$ (Fig. 7A). The decrease in darkness was $0.93( \pm 0.93$, $\mathrm{n}=3$ ) $\mathrm{g} \mathrm{AFDW} \mathrm{m}^{-2}$, but was not statistically significant (paired $t$-test, $t_{2}=1.72, p=0.228$ ). The loss in the light of $8.15( \pm 2.35) \mathrm{g} \mathrm{AFDW} \mathrm{m^{-2 }}$ was significant $\left(t_{2}=6.00\right.$, $p=0.027$ ) and 8.8 -fold higher than in darkness. During the summer experiment the leaves consistently lost more (2.5 to 5.4 times) organic matter in light than in darkness (Fig. 7B, Table 2). The difference was statistically significant already after $12 \mathrm{~d}$ (paired $t$-test, $t_{4}=$ $5.53, p=0.005$ ). Subtraction of the abiotic leaching in darkness from that in light (Fig. 7B) resulted in the sunlight-induced loss of organic matter (Fig. $7 \mathrm{C}$ ). The loss fitted well to first order decay kinetics (regression analysis, $\left.\mathrm{r}^{2}=0.99, F_{1,4}=698, \mathrm{p}<0.001\right)$. When expressed as a function of cumulative global radiation, the apparent first order decay coefficient was $0.000380 \mathrm{MJ}^{-1} \mathrm{~m}^{2}$.

The magnitude of leaching from leaves was followed by collecting water from petri dishes for the determination of DOC. In the solar radiation-exposed petri dishes the concentration of DOC increased during the course of accumulated radiation (Fig. 8A, B). In darkness the concentration of DOC remained constant (Fig. 8A, B) and in petri dishes without leaves was 5.68 $( \pm 0.64, \mathrm{n}=21) \mathrm{g} \mathrm{DOC}-\mathrm{C} \mathrm{m}^{-3}$ of littoral water (Fig. $8 \mathrm{~A}$ ). The petri dishes exposed to solar radiation, but not

Fig. 7 Zostera marina Relative changes (mean $\pm \mathrm{SD}$ ) in the AFDW of leaves kept in darkness (solid triangles) or exposed to solar radiation (open triangles) in (A) spring and $(B)$ summer compared to those recorded before the experiment. The number of sterile replicates was 3 in spring. In the summer the number of sterile replicates was $4,5,5,6$, 2 and 1 at time intervals from the start to the end, respectively. (C) Solar radiation-induced loss of AFDW during the summer experiment. The line describes decomposition according to the first order kinetics with an apparent decay coefficient of $0.000380 \mathrm{MJ}^{-1}$ $\mathrm{m}^{2}$ Only the cumulative amount of global radiation which penetrated into the petri dishes is included
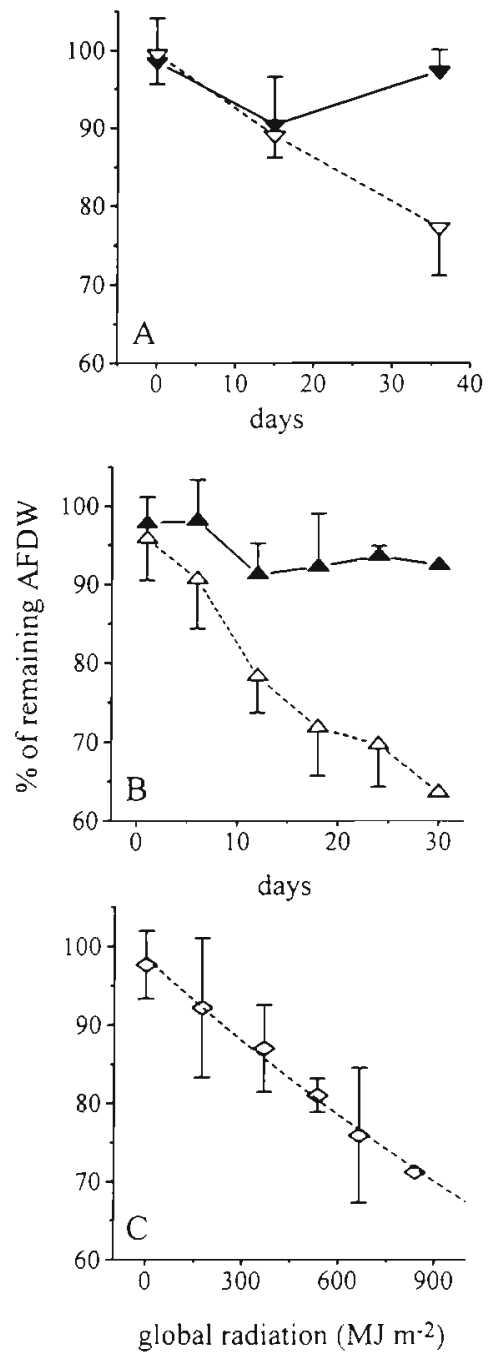
Table 2. Zostera marina. Initial, lost, leached and fragmented carbon of leaves (mean $\pm S D$ ) from the summer experiment. n: number of dark-light pairs which were confirmed to be sterile. DOC: dissolved organic carbon; FPOC: fine particulate organic carbon. nd: not determined

\begin{tabular}{|c|c|c|c|c|c|}
\hline Day & $\mathrm{n}$ & $\begin{array}{l}\text { Initial } \\
\text { carbon }^{\mathrm{a}}\end{array}$ & $\begin{array}{l}\text { Lost } \\
\text { carbon } \\
\operatorname{lg~C~m}^{-2}\end{array}$ & $\begin{array}{l}\text { Leached } \\
\text { DOC } \\
\text { eaves) }\end{array}$ & FPOC \\
\hline \multicolumn{6}{|c|}{ Dark } \\
\hline 1 & 4 & $11.89( \pm 0.34)$ & $0.23( \pm 0.69)$ & nd & $0.00( \pm 0.03)$ \\
\hline 6 & 5 & $11.91( \pm 0.61)$ & $0.21\{ \pm 1.04\}$ & nd & $0.00( \pm 0.01)$ \\
\hline 12 & 5 & $12.68( \pm 1.02\}$ & $1.11( \pm 0.27)$ & $1.02( \pm 0.52)$ & $-0.03( \pm 0.04)$ \\
\hline 18 & 5 & $13.42( \pm 0.96)$ & $1.55( \pm 0.63)$ & $1.49( \pm 1.29)$ & $-0.02( \pm 0.01)$ \\
\hline 24 & 2 & $13.77( \pm 1.41)$ & $0.88( \pm 0.53)$ & $0.70( \pm 0.02)$ & $-0.03( \pm 0.00)$ \\
\hline 30 & 1 & 8.71 & 0.66 & 0.80 & -0.01 \\
\hline \multicolumn{6}{|c|}{ Light } \\
\hline 1 & 4 & $11.89( \pm 0.34)$ & $0.51( \pm 0.66)$ & nd & $0.00( \pm 0.01)$ \\
\hline 6 & 5 & $11.91( \pm 0.61)$ & $1.14( \pm 0.79)$ & nd & $0.03( \pm 0.02)$ \\
\hline 12 & 5 & $12.68( \pm 1.02)$ & $2.76( \pm 0.61)$ & $2.91( \pm 0.85)$ & $0.02( \pm 0.02)$ \\
\hline 18 & 5 & $13.42\{ \pm 0.96\}$ & $4.11( \pm 0.52)$ & $6.36( \pm 3.78)$ & $0.07( \pm 0.04)$ \\
\hline 24 & 2 & $13.77( \pm 1.41)$ & $4.15( \pm 0.32)$ & $4.14( \pm 0.18)$ & $0.02( \pm 0.00)$ \\
\hline 30 & 1 & 8.71 & 3.17 & 7.14 & 0.11 \\
\hline
\end{tabular}

those in the dark, smelled of styrene. Photochemical depolymeration of polystyrene and the released styrene into water may have caused the increased concentration of DOC in solar radiation-exposed petri dishes (Andrady et al. 1995). The concentration of DOC was higher in the presence than in the absence of eelgrass in both light and darkness (Fig. 8A, B). The calculated leaching of DOC from leaves was higher under solar radiation than in darkness (Fig. 8C). Under solar radiation leaching showed a tendency to increase in relation to the accumulated global radiation (Fig. $8 \mathrm{C}_{\text {; }}$ regression analysis, $F_{1,11}=2.0, \mathrm{p}=0.18$ ). In darkness the concentration of DOC remained constant from Day 12 to 30 (Fig. $8 C_{i}$ regression analysis, $F_{1,11}=$ $0.10, p=0.75$ ), indicating that most leaching occurred before Day 12. This agrees with the 6 to $7 \%$ reduction in the AFDW content of leaves between Days 6 and 12 (paired $t$-test, $t_{5}=11.2, p<0.001$ ), and the fact that there was no further loss after Day 12 (Fig. 7B).

Fragmentation of leaves may have resulted in loss of organic matter. In darkness the fragmentation of leaves was negligible (Fig. 9, Table 2), indicating that leaching completely explained the loss of carbon from the leaves. Therefore it was possible to calculate, according to the relationship leached DOC vs AFDW, that the lost AFDW contained 37.2\% $( \pm 21, n=13)$ carbon. Solar radiation induced some fragmentation of leaves (Fig. 9). This fragmentation covered 1.1 to $3.5 \%$ of the lost carbon from leaves (Table 2). In the solar radiation-exposed leaves the leached DOC explained 100 to $225 \%$ of the lost carbon. Some of the leached DOC concentrations must be overestimates, probably due to interference of styrene, since it is unrealistic to trace more leached DOC than was lost from
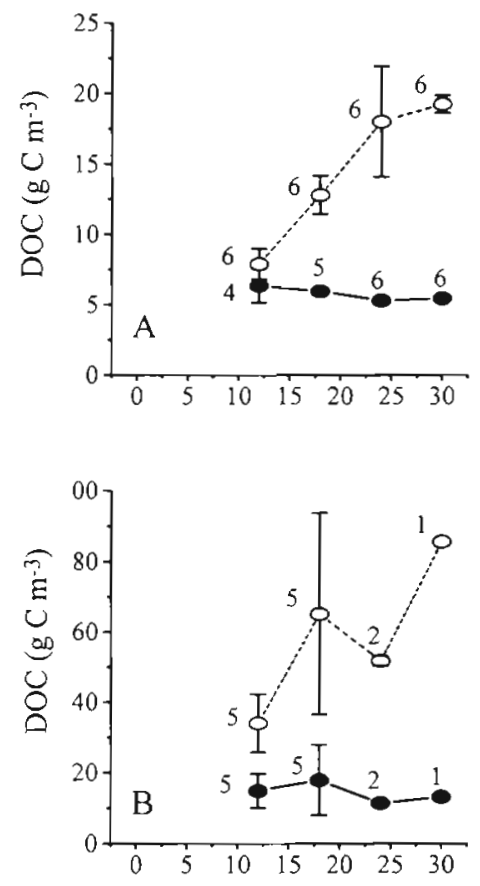

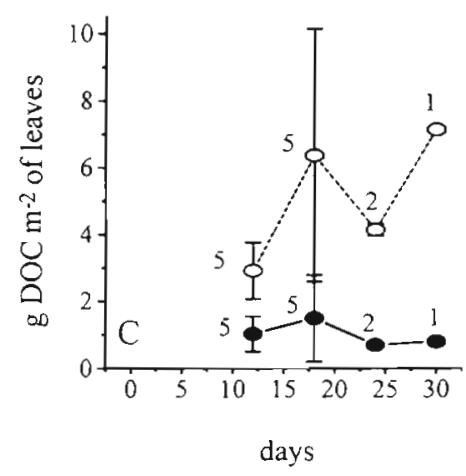

Fig. 9. Zostera marina. Fragmentation of fine particulate orgamic carbon (FPOC) from leaves during the summer experiment in darkness (and under solar radj.ation $(0$, mean $\pm S D)$

Fig. 8. Zostera marina Concentration of dissolved organic carbon dishes and the leaching leaves (mean \pm SD) hout leaves in darkness (@) and under Aadiation (O) (B) As in A, but in the presence of leaves. Number of samples analysed is shown be side the data points

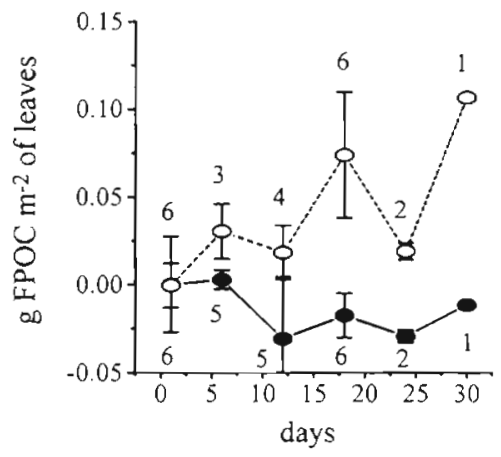


leaves. Although the DOC values under solar radiation were somewhat variable, they suggest that most of the leached carbon remained in the water and was not photochemically mineralised.

\section{Solar radiation-induced changes in the bioavailability of leaves}

The exposure to solar radiation changed the chemical structure of leaves (Figs. 2 to 7 , Table 1) and possibly also the bioavailability of organic matter. The detrital pieces of eelgrass exposed to solar radiation supported 2.1- to 3.4-fold higher bacterial activity than if kept in darkness (Fig. 10). This indicates that solar radiation increased the bioavailability of the detrital pieces of eelgrass.

Fig. 10. Zostera marina. Incorporation of ${ }^{14} \mathrm{C}$-leucine into bacterial macromolecules. The incorporation indicates the bioavailability of sterile leaves of eelgrass after incubation in darkness (-) or under solar radiation (O) (mean $\pm \mathrm{SD}$, $\mathrm{n}=6$ )

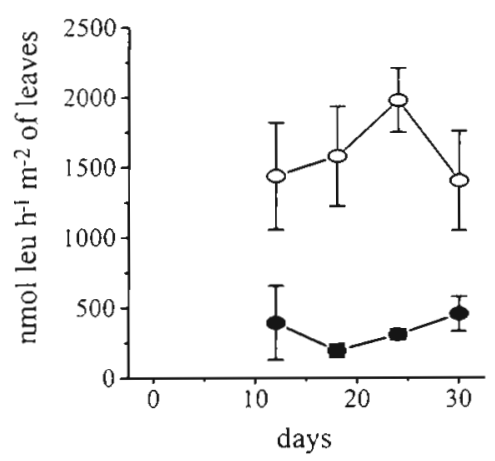

\section{DISCUSSION}

\section{Degradation of chl a from detrital leaves of eelgrass}

Degradation rates of $\mathrm{chl} \alpha$ in submerged angiosperms are slow or moderate (Pellikaan 1982, Bianchi \& Findlay 1991, Bianchi et al. 1991). In the presence of detrivores decay rates of chl a were 0.073 and $0.031 \mathrm{~d}^{-1}$ for Vallisneria americana and Potamogeton sp., respectively (Bianchi \& Findlay 1991). Biological degradation of chl a in Zostera marina is much slower than in V. americana and Potamogeton sp. Pellikaan (1982) found that throughout a 7 mo in situ incubation of $Z$. marina detritus which was sheltered from solar radiation inside a litterbag, the concentration of chl a remained high. In addition, detritus more than 1 yr old still had intact chloroplasts. The slow decay of chl a in darkness (Fig. 6) agrees with earlier reports on deliberate chl a loss from submerged angiosperms.

Photochemical reactions degrade photosynthetic pigments. Under artificial white light, photosynthetic pigments of isolated chloroplasts photodegrade rapidly (half life $<1 d_{i}$ Barry et al. 1990, Chauhan et al. 1992). These in vitro studies have shown that $\beta$-carotene is the most sensitive (Ridley 1977, Pallett \& Dodge 1979, Barry et al. 1990) and lutein the most resistant (Barry et al. 1990) pigment for photo-oxidation. Typically the photodegradation of chl a exceeds that of chl $b$ (Ridley 1977. Carpentier et al. 1986). When the pigments of fresh leaves were analysed in this study (Table 1), the concentration of $\beta$-carotene was low, the concentration of lutein was high and the chl $a / b$ ratio low in brown leaves relative to that found in green leaves (Table 1). The relative concentrations of pigments in brown leaves were similar to photodegraded chloroplasts. This suggests that photochemical destruction shapes the relative abundance of pigments already during the initial phases of decomposition.

The starting material of the summer experiment may be considered to represent leaves in the later phase of pigment decomposition, because the drying of leaves degraded most of the carotenoids and $2 / 3$ of chl $a$. The remaining chl a of these leaves degraded rapidly under solar radiation (Fig. 6). The photodegradation of $\mathrm{chl} a$ in aquifers is also a rapid process. In the presence of $10 \mu \mathrm{M} 3-\left(3^{\prime}, 4^{\prime}\right.$-dichlorophenyl)-1', $1^{\prime}$-dimethyl urea (DCMU; a herbicide, which blocks photosynthetic electron transfer at photosystem II), half of the chl $a$ in the euphotic zone of 3 lakes photodegraded in 0.23 to $0.79 \mathrm{~d}$ (Leavitt \& Carpenter 1990). In mid-latitude waters half of chl a can be calculated to photodegrade in $0.26 \mathrm{~d}$ at a depth of 1 optical attenuation (Nelson 1993). Although the above examples of photodegradation of chl a are not from detrital leaves of angiosperms, they support our finding that chl a photodegrades rapidly in solar radiation-exposed detrital leaves of eelgrass.

The heating of leaves before our experiment destroyed most carotenoids, including those which act as photoprotectants for chl a (Demming-Adams \& Adams 1996). Therefore, chl a photodegradation may have been overestimated in the summer experiment. However, photodegradation occurs also in the presence of fully operative protection machinery. In isolated chloroplasts $20 \%$ of chl a was photooxidised during 6 h of white light intensity of $250 \mu \mathrm{mol} \mathrm{m} \mathrm{m}^{-2} \mathrm{~s}^{-1}$ (Barry et al. 1990). The leaves in this study received PAR intensities of 500 to $1500 \mu \mathrm{mol} \mathrm{m} \mathrm{m}^{-2} \mathrm{~s}^{-1}$ in addition to the natural UV radiation. The high level of radiation in this study, compared to that of Barry et al. (1990), suggests that the photodegradation rates of chl a were realistic despite the lack of carotenoids.

The temperatures in the petri dishes exposed to solar radiation were higher than in petri dishes in darkness, with a maximum difference of $25^{\circ} \mathrm{C}$. This difference can be expected to induce thermal degradation. Indeed, Canjura et al. (1991) found that a $15^{\circ} \mathrm{C}$ increase 
in temperature doubled thermal degradation of $\operatorname{chl} a$. If the degradation in the dark petri dishes (considering it completely thermal) is doubled, the degradation rate of chl a under solar radiation would still be 8.4 times higher than in darkness. Since the biological degradation of chl a in detrital leaves of eelgrass is slow in darkness (Pellikaan 1982), photodegradation is the major pathway for chl a decay in eelgrass.

\section{Loss of colour and non-pigmented absorbing components from leaves}

Leaves of Zostera marina turn brown after death and light absorption increases dramatically throughout the spectrum (Fig. 2). The increased absorption accelerates the photochemical decay of the leaves because more light energy is trapped in the leaves. The exact mechanism for this change in optical properties is uncertain but probably involves both the formation of highly absorptive compounds and structural changes which increase internal reflection of light in the leaves. The highly absorbing compounds may have formed from lignin via photochemical yellowing (Leary 1968, Heither \& Schmidt 1991). Yellowing produces coloured quinoid structures and condensed aromatic groups. The cell walls of $Z$. marina contain $7.3 \%$ of lignin (Godshalk \& Wetzel 1978), which may act as a precursor of highly absorbing humic substances. Humic acid may form up to $4.2 \%$ of $Z$. marina detritus dry weight (Radwan et al. 1997) and is likely to contribute to the high absorption of brown leaves. At least leaves of $Z$. noltii contain high concentration of metals (Wasserman \& Dumon 1995). Metals are likely to form complexes with humic acid and intensify absorption by humic acid.

This study and that of Boon \& Haverkamp (1982) show that solar radiation reduces effectively the absorbance in leaves of detrital eelgrass. Loss of colour is expected, because the absorbing components of leaves, pigments, and humic acids are all sensitive to photobleaching. Dissolved humic substances lose their absorbance and aromacity during exposure to UV radiation (Allard et al. 1994) and to solar radiation (Kieber et al. 1990, De Haan 1993). In accordance, photobleached leaves of Halodule wrightii are devoid of aromatic compounds (Opsahl \& Benner 1993). Although the photobleaching of aquatic macrophytes is a relatively new finding in science (Boon \& Haverkamp 1982, Opsahl \& Benner 1993, this study), the phenomenon has been applied in traditional Japanese paper (Washi) making. In the production of white paper the raw material, bark of, for example, Paper-mulberry (Broussonetia kazinoki Sieb.) is submerged in shallow water and exposed to solar radiation for 1 to $10 \mathrm{~d}$ (Hamada 1991).

\section{Loss of organic matter from leaves}

The photodegradable components of leaves, pigments and lignin or humic acids, form less than $10 \%$ of the total organic matter (Table 1; Godshalk \& Wetzel 1978, Opsahl \& Benner 1993, Radwan et al. 1997). Since the solar-induced loss of organic matter was 23 to $36 \%$ (Fig. 7, Table 2), compounds other than those mentioned above were involved in the loss of organic matter. It is possible that the light-absorbing compounds cause indirect (sensitised) photochemical degradation of non-absorbing compounds like structural carbohydrates (Andrady et al. 1995). In addition, photodegradation of lignin (Opsahl \& Benner 1993) leads to loss of connections between the structural carbohydrate fibrils. As was found in this study, this process makes cell walls leaky and induces a slight fragmentation of leaves on which no animals or microbes are present.

The enhancement of organic matter loss by solar radiation (Fig. 7) may be partly explained by a temperature difference (maximum of $25^{\circ} \mathrm{C}$ ) between light and dark petri dishes. According to the Arrhenius equation, a $25^{\circ} \mathrm{C}$ decrease in temperature will reduce the rate constant of solar radiation-induced loss by $68 \%$ (Fig. $7 \mathrm{C}$ ). If this theoretical overestimation is taken into account, the loss of organic matter from leaves (Fig. 7B, Table 2) would still be 1.4 to 2.4 times higher under solar radiation than in darkness. Thus, the solar radiation, not the temperature difference, was the main factor inducing the loss of organic matter from leaves.

The impact of solar radiation on the decomposition of detrital eelgrass leaves can be estimated according to the first order decay model (Eq. 1, Fig. 7C). The area of leaves exposed to solar radiation and the cumulative load of solar radiation are the only input parameters for this decay model. The model works in a situation where brown leaves of eelgrass are floating in surface waters, and it should be independent of biological interference. A large number of detrital leaves of eelgrass will also be exposed to solar radiation at the bottom of shallow waters (Thayer et al. 1977, Pellikaan \& Nienhuis 1988). In these cases the absorption of DOM and suspended matter in littoral waters reduces the irradiance reaching detritus at the bottom. The reduced intensity of solar radiation has to be taken into account in the application of the model. However, the model should be used with caution due to spectral changes in irradiation with depth. The UV and blue parts of the spectrum do not penetrate deep into coastal water. Because the UV and blue parts of the spectrum can be expected to play the largest role in inducing photochemical decomposition (Moran \& Zepp 1997), the photochemical decomposition at a few meters depth may be slower than estimated according to our model. 


\section{Enhanced bioavailability of photobleached leaves}

The leaves of seagrasses usually lose a remarkably large part (20 to $58 \%$ ) of their organic matter within the first ( 1 to 7 ) days of degradation (e.g. Harrison 1989, Blum \& Mills 1991, Hemminga \& Nieuwenhuize 1991, Opsahl \& Benner 1993). After the initial fast loss process, the detrital leaves of seagrasses lose their organic matter content very slowly (decay rates 0.0018 to $0.003 \mathrm{~d}^{-1}$; Wahbeh \& Mahasneh 1985, Kristensen 1994) or not at all (Harrison \& Mann 1975, Pellikaan 1984). Godshalk \& Wetzel (1978) suggested that the relatively high content of structural tissue in Zostera marina leaves makes the leaves resistant to degradation. In addition, fresh seagrass leaves contain a variety of phenols (Zapata \& McMillan 1979), and those found in $Z$. marina can inhibit bacterial growth (Harrison 1982). Solar radiation-induced degradation seems to affect both of the suggested reasons for recalcitrance. First, the leaves lose phenols during photobleaching (Opsahl \& Benner 1993). Moreover, solar radiation-induced fragmentation reduces structural barriers in leaves and exposes new microniches to colonisation by bacteria

As shown by numerous litterbag experiments, physical fragmentation of leaves is an important factor in the progress of decomposition. Fragmentation increases the surface area of detritus and enhances bacterial metabolism on detritus (Fenchel 1970, Harrison \& Mann 1975). Therefore, the combined action of solar radiation, physical and biological fragmentation and microbial decomposition will probably speed up the loss of organic matter, resulting in greater loss than that observed in this study.

The results of this study show that solar radiation. accelerates degradation of detrital leaves of eelgrass both indirectly and directly. The direct effects of solar radiation induce loss of organic matter from leaves (Fig. 7. Table 2). This occurs partly via fragmentation (Fig. 9) but mainly via increased leaching of DOC from leaves (Fig. 8, Table 2). Leaves quickly lose their absorbing compounds, especially chl a, under exposure to solar radiation (Figs, 2 to 6 , Table 1). The solar radiation increases the bioavailability of leaves to bacteria, and this is expected to enhance degradation indirectly (Fig. 10). Based on our results, we propose that the previous model on the decomposition of aquatic angiosperms (Godshalk \& Wetzel 1978) should be modified. Solar radiation must be taken into account in the decomposition of leaf litter.

Acknowledgements. We thank Charlotte Anderson and Anne Jacobsen for skilful technical assistance. We appreciate the critical comments of an anonymous reviewer on our manuscript. A.V. was supported by a Danish Government Scholarship, the Finnish Centre for International Mobility and the
Finnish Doctoral School of Environmental Ecology, Ecotoxicology, and Ecotechnology. The values for global irradiation were kindly supplied by the Department of Agricultural Sciences, The Royal Vetermary and Agricultural University, Copenhagen, Denmark. This study was supported by the Danish Environmental Research Programme (SMP) and the Carlsberg Foundation.

\section{LITERATURE CITED}

Allard B, Borén H, Pettersson C, Zhang G (1994) Degradation of humic substances by UV irradiation. Environ Int 20: 97-101

Andrady AL, Amin MB, Hamid SH, Hu X, Torikai A (1995) Effects of increased solar ultraviolet radiation on materials. Ambio 24:191-196

Barry P, Young AJ, Britton G (1990) Photodestruction of pigments in higher plants by herbicide action. J Exp Bot 41: $123-129$

Bianchi TS, Findlay S (1991) Decomposition of Hudson estuary macrophytes: photosynthetic pigment transformations and decay constants. Estuaries 14:65-73

Bianchi TS, Findlay S, Fontvieille D (1991) Experimental degradation of plant materials in Hudson River sediments. I. Heterotrophic transformation of plant pigments. Biogeochemistry 12:171--187

Blum LK, Mills AL (1991) Microbial growth and activity during the initial stages of seagrass decomposition. Mar Ecol Prog Ser 70:73-82

Boon JJ, Haverkamp J (1982) Pyrolysis mass spectrometry of intact and decomposed leaves of Nuphar variegatum and Zostera marina, and some archaeological eelgrass samples. Hydrobiol Bull 16:71-82

Canjura FL, Schwartz SJ, Nunes RV (1991) Degradation. kinetics of chlorophylls and chlorophyllides. J Food Sci 56 : $1639-1643$

Carpentier R, Leblanc RM, Bellmare G (1986) Chlorophyl photobleaching in pigment-protein complexes. Z Naturforsch Sect C J Biosci 41:284-290

Chauhan NP, Fatma T, Mishara RK (1992) Protection of wheat chloroplasts from lipid peroxidation and loss of photosynthetic pigments by quercetin under strong illumination. J Plant Physiol 140:409-413

De Haan H (1993) Solar UV-light penetration and photodegradation of humic substances in peaty lake water. Limnol Oceanogr 38:1072-1076

Demmig-Adams B, Adams WW (1996) The role of xanthophyll cycle carotenoids in the protection of photosynthesis. Trends Plant Sci 1:21-26

Fenchel $T$ (1970) Studies on the decomposition of organic detritus from the turtle grass Thalassia testudinum. Limnol Oceanogr 15:14-20

Goldshalk GL, Wetzel RG (1978) Decomposition of aquatic angiosperms. III. Zostera marina L. and a conceptual model of decomposition. Aquat Bot 5:329-354

Hamada K (1991) What kind of methods are there to make the paper white? In: Taki $C$ (ed) A handbook of the art of Washi-a collection of questions and answers. Wagamido KK, Tokyo, p 32-33

Harrison PG (1982) Control of microbial growth and amphipod grazıng by water-soluble compounds from leaves of Zostera marina. Mar Biol 67:225-230

Harrison PG (1989) Detrital processing in seagrass systems: a review of factors affecting decay rate, remineralization and detrivory. Aquat Bot 23:263-288 
Harrison PG, Mann KH (1975) Detritus formation from eelgrass (Zostera marina L.): the relative effects of fragmentation, leaching and decay. Limnol Oceanogr 20:924-934

Heitner C, Schmidt JA (1991) Light induced yellowing of wood-containing papers - a review of fifty years of research. Proc 6th Int Symp Wood Pulping Chemistry. Appita, Parkville, 1:131-149

Hemminga MA, Nieuwenhuize J (1991) Transport, deposition and in situ decay of seagrasses in a tropical mudflat area (Banc D'arguin, Mauritania). Neth J Sea Res 27. $183-190$

Hollibaugh JT, Wong PS (1992) Ethanol-extractable substrate pools and the incorporation of thymidine, L-leucine, and other substrates by bacterioplankton. Can J Microbiol 38: $605-613$

Jeffrey SW (1997) Preparation of chlorophyll standards. In: Jeffrey SW, Mantoura RFC, Wright SW (eds) Phytoplankton pigments in oceanography: guidelines to modern methods. UNESCO, Paris, p 207-238

Kieber RJ, Zhou X, Mopper K (1990) Formation of carbonyl compounds from UV-induced photodegradation of humic substances in natural waters: fate of riverine carbon in the sea. Limnol Oceanogr 35:1503-1515

Kristensen E (1994) Decomposition of macroalgae, vascular plants and sediment detritus in seawater: use of stepwise thermogravimetry. Biogeochemistry 26:1-24

Leary GJ (1968) Photochemical production of quinoid structures in wood. Nature 217:672-673

Leavitt PR, Carpenter SR (1990) Regulation of pigment sedimentation by photo-oxidation and herbivore grazing. Can J Fish Aquat Sci 47:1166-1176

Mann KH (1972) Macrophyte production and detritus food chains in coastal waters. Mem Ist Ital Idrobiol 29:353-383

Mann KH (1988) Production and use of detritus in various freshwater, estuarine, and coastal marine ecosystems. Limnol Oceanogr 33:910-930

Moran MA, Zepp RG (1997) Role of photoreactions in the formation of biologically labile compounds from dissolved organic matter. Limnol Oceanogr 42:1307-1316

Nelson JR (1993) Rates and possible mechanism of lightdependent degradation of pigments in detritus derived from phytoplankton. J Mar Res 51:155-179

Nienhuis PH, Groenendijk AM (1986) Consumption of eelgrass (Zostera marina) by birds and invertebrates: an annual budget. Mar Ecol Prog Ser 29:29-35

Odum WE (1984) Dual-gradient concept of detritus transport and processing in estuaries. Bull Mar Sci 35:510-521

Opsahl S, Benner R (1993) Decomposition of senescent blades

Edtorial responsibility: Otto Kinne (Editor),

Oldendorf/Luhe, Germany of the seagrass Halodule wrightii in a subtropical lagoon. Mar Ecol Prog Ser 94:191-205

Pallett KE, Dodge AD (1979) The role of light and oxygen in the action of photosynthetic inhibitor herbicide monouron. Z Naturforsch Sect C J Biosci 34:1058-1061

Pellikaan GC (1982) Decomposition processes of eelgrass, Zostera marina L. Hydrobiol Bull 16:83-92

Pellikaan GC (1984) Laboratory experiments on eelgrass (Zostera marina L.) decomposition. Neth J Sea Res 18: $360-383$

Pellikaan GC, Nienhuis PH (1988) Nutrient uptake and release during growth and decomposition of eelgrass. Zostera marina $\mathrm{L}$, and its effects on the nutrient dynamics of lake Grevelingen. Aquat Bot 30:189-214

Radwan A, Davies G, Fataftah A, Ghabbour EA, Jansen SA, Willey RJ (1997) Isolation of humic acid from the brown algae Ascophyllum nodosum, Fucus vesiculosus, Laminaria saccharina and the marine angiosperm Zostera marina. J Appl Phycol 8:553-562

Ridley SM (1977) Interaction of chloroplast with inhibitors Induction of chlorosis by diuron during prolonged illumination in vitro. Plant Physiol 59:724-732

Rublee PA, Roman MR (1982) Decomposition of turtlegrass (Thalassia testudium Konig) in flowing sea-water tanks and litterbags: compositional changes and comparison with natural particulate matter. J Exp Mar Biol Ecol 58: $47-58$

Sendergaard M, Middelboe M (1993) Measurements of particulate organic carbon: a note on the use of glass fiber $\left(\mathrm{GF} / \mathrm{F}\right.$ ) and Anodisc ${ }^{13}$ filters. Arch Hydrobiol 127:73-85

Thayer GW, Engel DW, LaCroix MW (1977) Seasonal distribution and changes in the nutritive quality of living, dead and detrital fractions of Zostera marina L. J Exp Mar Biol Ecol 30:109-127

Wahbeh MI, Mahasneh AM (1985) Some aspects of decomposition of leaf litter of the seagrass Halophila stipulacea from the Gulf of Aqaba (Jordan). Aquat Bot 21:237-244

Wasserman JC, Dumon JC (1995) Metal and organic matter release in early stages of decomposition of eelgrass (Zostera noltii Hornemann). Environ Technol 16: $1125-1134$

Wright SW, Jeffrey SW, Mantoura RFC, Llewellyn CA, Bjørnland T, Repeta D. Welschmeyer N (1991) Improved HPLC method for the analysis of chlorophylls and carotenoids from marine phytoplankton. Mar Ecol Prog Ser 77: $183-196$

Zapata O, McMillan C (1979) Phenolic acids in seagrasses. Aquat Bot 7:307-317

Submitted: February 16, 1998; Accepted: May 15, 1998

Proofs received from author(s): August 3, 1998 